\title{
Interest in screening examinations among cancer patients
}

\author{
Zainteresowanie badaniami profilaktycznymi wśród osób chorujących na nowotwór
}

\section{Ewa Humeniuk', Olga Dąbska', Katarzyna Pawlikowska-Łagód², Anna Goś3 , Małgorzata Matuska ${ }^{1}$}

\begin{abstract}
'Department of Pathology and Rehabilitation of Speech, Faculty of Nursing and Health Sciences, Medical University of Lublin

Zakład Patologii i Rehabilitacji Mowy, Wydział Nauk o Zdrowiu, Uniwersytet Medyczny w Lublinie 2 Department of Ethics and Human Philosophy, Faculty of Nursing and Health Sciences, Medical University of Lublin Zakład Etyki i Filozofii Człowieka, Wydział Nauk o Zdrowiu, Uniwersytet Medyczny w Lublinie ${ }^{3}$ Department of Foreign Languages, Faculty of Nursing and Health Sciences, Medical University of Lublin Studium Praktycznej Nauki Języków Obcych, I Wydział Lekarski z Oddziałem Stomatologicznym, Uniwersytet Medyczny w Lublinie
\end{abstract}

CORRESPONDING AUTHOR/AUTOR DO KORESPONDENCJ:

Olga Dąbska

Gózd Lipiński 49A, 23-425 Biszcza e-mail: olga.dabska@umlub.pl

\section{STRESZCZENIE ZAINUERESOWANIE BADANIAMI PROFILAKUYCZNYMI WŚRÓD OSÓB CHORUJACYCH NA NOWOWÓR}

Cel pracy. Określenie wpływu zmiennych socjo-demograficznych na korzystanie z badań profilaktycznych przez osoby chorujące na nowotwór.

Materiał i metodyka. Grupę badaną stanowiło 100 osób chorych na nowotwór. Posłużono się metodą sondażu diagnostycznego, techniką ankietową. Narzędziem badawczym była autorska ankieta, badająca zainteresowanie chorych na nowotwór badaniami profilaktycznymi. Analizy materiału badawczego dokonano przy użyciu pakietu statystycznego STATISTICA 12 i programu Microsoft Office Excel. Przyjęto poziom istotności p<0,05, wskazujący na istotne statystycznie różnice bądź zależności. Wykorzystano test Chi Wyniki. Ankietowani przeważnie nie korzystali ze screeningu przeznaczonego do wykrycia choroby nowotworowej (66\%). Uczestnictwo w badaniach profilaktycznych determinowały wiek $(p=0,05)$, płeć $(p=0,003)$, miejsce zamieszkania $(p=0,04)$ badanych. Na korzystanie $z$ badań profilaktycznych nie wpływały stan cywilny $(p=0,47)$, poziom wykształcenia $(p=0,85)$ i sytuacja materialna $(\mathrm{p}=0,13)$ respondentów.

Wnioski. Proces ograniczenia zachorowalności i umieralności z powodu chorób nowotworowych wymaga większego uczestnictwa populacji w programach profilaktycznych.

Słowa kluczowe: nowotwory, screening, profilaktyka drugorzędowa, badania przesiewowe

\section{ABSTRACT WNEREST IN SCREENING EXAMINATIONS AMONG CANCER PATIENTS}

Aim. To determine the influence of socio-demographic variables on attendance rate at screening examinations in cancer patients.

Material and methods. The research group comprised of 100 cancer patients. The method applied in the research was a diagnostic survey. The research instrument was the authors' own questionnaire specially compiled to measure cancer patients' interest in screening examinations. The research material was analysed with the statistical packet STATISTICA 12 and Microsoft Office Excel software. Significance level was assumed at $p<0.05$ to determine statistically significant differences and dependencies. A Chi ${ }^{2}$ test was used in the research.

Results. The surveyed patients mostly did not participate in screening examinations aimed at diagnosing cancer (66\%). Their Age $(p=0.05)$, gender $(p=0.003)$ and place of residence $(p=0.04)$ determined their participation rate in screening tests. The patients ${ }^{\prime}$ marital status $(p=0.47)$, education ( $p=0.85)$ and economic status $(p=0.13)$ did not affect their willingness to attend screening examinations.

Conclusions. The process of cancer incidence and death rate limitation requires greater participation of the population in prevention programmes.

Key words: $\quad$ cancer, screening, secondary prevention

\section{INTRODUCTION}

Cancer constitutes the second cause of death and accordingly important socio-economic and demographic problem in Polish society [1]. In 2013, it contributed to $23 \%$ of deaths among women and $26 \%$ of deaths among men [2]. The total number of cancer incidence and death rate is forecast to rise gradually in the immediate future and to become the main cause of death in people of both genders up to 65 years of age. In recent years, the incidence of malignant tumours in men has maintained at a steady level. In turn, in the population of women 
the incidence of cancer is constantly increasing [3]. The most common cancer diagnoses in men include malignant lung carcinoma, prostate cancer, colon cancer, urinary bladder cancer and gastric cancer. Whereas women are most frequently diagnosed with malignant breast tumour, colon cancer, lung cancer, endometrial cancer, ovarian cancer and cervical cancer. Lung cancer is the most common cause of death in both genders [4]. According to Tuchowska et al. the reason for the growing incidence and death rate of cancer in Poland is, apart from exposition to risk factors, delay in implementing prevention programmes compared to other countries [3]. Early cancer diagnosis is possible thanks to screening, namely secondary prevention. Screening examinations are particularly addressed to the population that is the most prone to cancer [5], what results in greater effectiveness of the treatment [6].

\section{AIM}

To determine the influence of the socio-demographic variables on the attendance rate at screening examinations in cancer patients.

\section{MATERIAL AND METHODS}

The research group comprised of 100 patients suffering from cancer. The respondents were 21-27 years old, mean age was $46.22 \pm 12.80$ years of age. The vast majority of the research sample constituted females (69\%) who dwelled in urban areas (66\%) and were married (45\%). Individuals with secondary (49\%) and vocational (31\%) education were dominant in the research sample. The surveyed patients assessed their economic status as good (57\%).

The method applied in the research was a diagnostic survey. The research instrument was the authors' own questionnaire specially compiled to assess cancer patients' interest, namely attendance rate at screening examinations. The tool consisted of close-ended single-choice questions and semi-open questions that required the opinion of the surveyed patients. The tool was also provided with a questionnaire concerning socio-demographic factors. Participation in the research was voluntary, individual and anonymous and was performed in accordance with the principles of the Declaration of Helsinki. Analysis of the research material was conducted with statistical packet STATISTICA 12 and Microsoft Office Excel software. The significance level was assumed at $\mathrm{p}<0.05$ which indicated statistically significant differences or dependencies. A Chi ${ }^{2}$ test was used in the research.

\section{RESULTS}

The research performed indicate that the surveyed patients mainly did not participate in screening aimed at diagnosing cancer (66\%). Merely $1 / 3$ of the surveyed people reported participation in screening tests. The examinations included mammography $(50 \%, n=17)$, ultrasound examination $(47 \%, \mathrm{n}=16)$, magnetic reso- nance imaging (MRI) $(6 \%, \mathrm{n}=2)$, computed tomography (CT) $(6 \%, n=2)$, X-ray $(3 \%, n=1)$, scintigraphy $(3 \%, n=1)$, biopsy $(3 \%, n=1)$, cervical smear $(3 \%, n=1)$, colonoscopy $(3 \%, n=1)$. Statistically significant dependency between the age $(\mathrm{p}=0.05)$, gender $(\mathrm{p}=0.003)$, place of residence $(\mathrm{p}=0.04)$ and participation in screening examinations was observed. It was noted that the older the patients, the more frequently they attended screening tests. Females $(43 \%, n=30)$ and city dwellers $(41 \%, n=27)$ participated in screening examinations significantly more frequently than males and surveyed individuals who lived in rural areas $(21 \%, n=7)$. The analysis performed did not reveal statistically significant relations between the remaining sociodemographic variables and the patients' participation rate in screening examinations. However, it was observed that single patients $(38 \%, \mathrm{n}=17)$ with secondary education $(37 \%)$ who declared average or bad economic status (43\%) underwent screening examinations slightly more frequently. The results obtained are presented in Table 1.

Tab. 1. Participation in screening examinations depending on the sociodemographic variables

\begin{tabular}{|c|c|c|c|c|}
\hline \multirow{3}{*}{ Variable } & \multicolumn{4}{|c|}{ Participation in screening examinations } \\
\hline & \multicolumn{2}{|c|}{ yes } & \multicolumn{2}{|c|}{ no } \\
\hline & $\mathrm{n}$ & $\%$ & $\mathrm{n}$ & $\%$ \\
\hline \multicolumn{5}{|l|}{ Age } \\
\hline below 40 years old & 7 & 21 & 26 & 79 \\
\hline 41-50 years old & 8 & 30 & 19 & 70 \\
\hline over 50 years old & 19 & 47.5 & 21 & 52.5 \\
\hline \multicolumn{5}{|c|}{ Statistical analysis: $\mathrm{Chi}^{2}=5.88 ; \mathrm{p}=0.05$} \\
\hline \multicolumn{5}{|l|}{ Gender } \\
\hline women & 30 & 43 & 39 & 57 \\
\hline men & 4 & 13 & 27 & 87 \\
\hline \multicolumn{5}{|c|}{ Statistical analysis: Chi $^{2}=8.91 ; p=0.003$} \\
\hline \multicolumn{5}{|l|}{ Marital status } \\
\hline single & 17 & 31 & 38 & 69 \\
\hline in a relationship & 17 & 38 & 28 & 62 \\
\hline \multicolumn{5}{|c|}{ Statistical analysis: $\mathrm{Chi}^{2}=0.52 ; \mathrm{p}=0.47$} \\
\hline \multicolumn{5}{|l|}{ Place of residence } \\
\hline urban areas & 27 & 41 & 39 & 59 \\
\hline rural areas & 7 & 21 & 27 & 79 \\
\hline \multicolumn{5}{|c|}{ Statistical analysis: $\mathrm{Chi}^{2}=4.13 ; \mathrm{p}=0.04$} \\
\hline \multicolumn{5}{|l|}{ Education } \\
\hline primary/vocational & 11 & 31 & 24 & 69 \\
\hline secondary & 18 & 37 & 31 & 63 \\
\hline higher & 5 & 31 & 11 & 69 \\
\hline \multicolumn{5}{|c|}{ Statistical analysis: $\mathrm{Chi}^{2}=0.32 ; \mathrm{p}=0.85$} \\
\hline \multicolumn{5}{|l|}{ Economic status } \\
\hline good/very good & 18 & 29 & 45 & 71 \\
\hline average/bad & 16 & 43 & 21 & 57 \\
\hline \multicolumn{5}{|c|}{ Statistical analysis: $\mathrm{Chi}^{2}=2.24 ; \mathrm{p}=0.13$} \\
\hline $\begin{array}{l}\text { n- numerosity, \% - percen } \\
\text { result }\end{array}$ & cance I & & & \\
\hline
\end{tabular}




\section{DISCUSSION}

In the opinion of Synowiec-Piłat, the social phenomenon of cancerophobia, namely fatal beliefs concerning cancer, is one of the reasons for little interest in oncologic screening in Poland [7]. Whereas Marcinkowska et al. distinguished four causes of low attendance rate at screening: economic, social, organisational and psychological ones [8]. The surveyed patients explain the fact of not attending screening examinations by neglecting health, low awareness of health or life hazards, postponing, lack of free time, underestimating the problem, lack of the belief that screening is effective, embarrassment during examination, conviction that the examination is painful. Reluctance to screening also results from poor organization of the tests, lack of trust in doctors' competences and equipment efficiency as well as stereotypes that prevail in the society (it is better not to know, let sleeping dogs lie, et cetera) [9-13].

Zatoński informs that popularisation of screening examinations for cancer should be particularly aimed at women due to constantly growing incidence and death rate of cancer in females. The tests should be popularised especially among the population of patients with low education and economic status. [14]. According to Wender, sending personal invitations to attend screening tests is one of the most efficient methods of increasing screening attendance rate [15]. Whereas, according to Szkiela et al., a higher attendance rate at screening is provided by easy, painless, non-invasive, socially accepted examination [5]. According to Godlewski et al., screening tests should be highly specific, sensitive and valuable as well as inexpensive, easy to perform, accessible and non-invasive [16]. Marcinkowska et al. claim that increasing screening attendance rate is achievable through the use of social information programmes aimed at realising the benefits of regular check-ups. They also highlight the crucial role of doctors that should involve promoting screening tests in the course of their daily work [17]. Kulik et al. stress the issue of insufficient financial means in primary health care devoted to cancer prevention [18]. Huand et al. report that from the point of view of economy of health, performing screening tests for cancer is highly beneficial [19]. Similarly, according to Miller et al., participation in screening improves diagnosis of cancer at an early stage of its development and thus enables undertaking treatment more rapidly and reducing its costs [20].

"In oncology, screening examinations are aimed at revealing cancer at the asymptomatic, subclinical stage that enables significant cancer recovery" [21]. According to Tuchowska et al., screening for cervical cancer - cervical smear, breast cancer - mammography, ultrasound examinations and magnetic resonance imaging, colon cancer - faecal occult blood tests and colonoscopy, are the most effective [3]. Also Chudzik reports the aforementioned tests as the most frequently used and effective oncologic screening [22]. The surveyed patients in the authors' own research most frequently underwent mammography, ultrasound examination, magnetic resonance imaging, computed tomography, X-ray examinations, scintigraphy, cervical smear and colonoscopy.

According to Szynglarewicz et al., a well-organised screening programme can significantly reduce death rate due to cancer diseases. However, attendance rate of women from Lower Silesia invited to mammography accounted for merely 41\% [23]. Pacian et al. assessed the level of knowledge and attitudes of women from the Lublin macro-region in terms of breast cancer prevention. The surveyed women listed the Internet (56\%) and television (53\%) as the main sources of knowledge about the disease. However, only half of the respondents used the sources regularly. The researchers highlight that constant improvement of social awareness of cancer through pro-health education and promotion of healthy lifestyle is essential [24]. Kozłowska and Kowalczyk researched the level of knowledge and attitudes of office workers in terms of Screening Programme for Early Colorectal Cancer Diagnosis. Only a quarter of the surveyed employees received information on the programme for early colorectal cancer diagnosis and they included more frequently city dwellers, women over 50 years of age, divorced, with the family history of colorectal cancer. Among the people who declared familiarity with the programme, only a scarce group had complete knowledge on the target group of the discussed screening. The office workers showed little interest in oncologic screening and the fact of having the family history of cancer did not incline them to the change of the attitude [6]. Among the people surveyed by El Fakir et al. only $35.7 \%$ of the respondents attended screening tests. Married women with the family history of breast cancer outnumbered the group [25]. Hofvind et al. achieved significantly better results since the attendance rate in the Norwegian programme reached 76.2\% [26]. Leżnicka et al. highlighted the discrepancy between the attendance rate of Polish women in screening cervical smear test, which reached $11-32 \%$, and the one achieved in Denmark - 75\%, in the Netherlands - 77\% or in Finland - 93\% [27]. Similarly to the aforementioned research, in the authors' own research, the respondents showed a very low level of interest in oncologic screening which was estimated at $34 \%$. Women over 50 years of age who lived in a city, were in relationship and declared average economic status underwent screening more frequently.

In the research by Nowakowska and Kabura, the respondents rated attending screening tests and following the rules of prevention as highly significant. "Apart from that, half of the respondents declared not making use of the prevention programmes. The society has the awareness of the significance of prevention but it is not reflected in their everyday lives" [28]. "The assumption that "it is better to prevent than treat" seems widely spread and grounded in the social awareness (...) In reality, it turns out that prevention is often underestimated and secondary. Both the society and doctors frequently focus on the problems of diagnosis and treatment and omit the vast potential that primary and secondary prevention - namely a series of actions aimed at reducing the probability of suffering from a malignant cancer-have" [29]. 


\section{CONCLUSIONS}

1. The results of the research show that the respondents mainly have not attended screening aimed at diagnosing cancer.

2. Age, gender, place of residence of the respondents determined their attendance rate at screening tests.
3. Marital status, level of education and economic status of the respondents did not affect their attendance rate at screening tests.

4. The process of limiting incidence and death rate due to cancer requires the population's greater participation rate at screening programmes.

\section{Zainteresowanie badaniami profilaktycznymi wśród osób chorujących na nowotwór}

\section{WPROWADZENIE}

Choroby nowotworowe są drugą przyczynę zgonów, w związku z tym stanowią istotny problem społecznoekonomiczny i demograficzny w polskim społeczeństwie [1]. W roku 2013 przyczyniły się do 23\% zgonów wśród kobiet i 26\% zgonów u mężczyzn [2]. Prognozuje się, iż w niedalekiej przyszłości ogólna liczba zachorowań oraz zgonów z powodu chorób nowotworowych będzie systematycznie rosnąć i stanie się główną przyczyną umieralności ludności obu płci do 65. r.ż. Zachorowalność na nowotwory złośliwe wśród mężczyzn utrzymuje się $\mathrm{w}$ ostatnich latach na stałym poziomie. Z kolei w populacji kobiet zachorowalność nowotworowa stale wzrasta [3]. Wśród mężczyzn diagnozuje się najczęściej nowotwory złośliwe płuca, gruczołu krokowego, jelita grubego, pęcherza moczowego, żołądka. Z kolei kobiety najczęściej chorują na nowotwór złośliwy piersi, jelita grubego, płuca, trzonu macicy, jajnika, szyjki macicy. Najczęstszą przyczynę zgonów u przedstawicieli obu płci stanowi rak płuca [4]. Zdaniem Tuchowskiej i wsp. powodem rosnącej zachorowalności i umieralności na choroby nowotworowe w Polsce jest oprócz ekspozycji na czynniki ryzyka, opóźnienie we wprowadzaniu programów profilaktycznych w porównaniu z innymi krajami [3]. Wczesne wykrywanie chorób nowotworowych możliwe jest dzięki badaniom przesiewowym, tzw. screeningu stanowiącego formę prewencji drugorzędowej. Badania screeningowe skierowane są zwłaszcza do populacji o największym prawdopodobieństwie rozwoju nowotworu [5], co w konsekwencji zapewnia większą skuteczność podjętej terapii [6].

\section{CEL PRACY}

Określenie wpływu zmiennych socjo-demograficznych na korzystanie z badań profilaktycznych przez osoby chorujące na nowotwór.

\section{MATERIAŁ I METODA}

Grupę badaną stanowiło 100 chorych na nowotwór. Respondenci byli w wieku 21-72 lat, średnia wieku wynio-

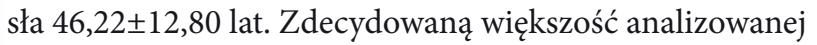
próby stanowiły kobiety (69\%), mieszkańcy miast (66\%), osoby w związku małżeńskim (45\%). W badanej grupie dominowały osoby ze średnim (49\%) i zawodowym wykształceniem (31\%). W samoocenie badanych, sytuację materialną postrzegano zazwyczaj, jako dobrą (57\%).

Posłużono się metodą sondażu diagnostycznego, techniką ankietową. Narzędziem badawczym był autorski kwestionariusz ankiety, badający zainteresowanie osób chorych na nowotwór badaniami profilaktycznymi. Narzędzie składało się z pytań zamkniętych jednokrotnego wyboru i półotwartych z możliwością wyrażenia własnej opinii. Ankietę opatrzono metryczką z pytaniami o czynniki socjo-demograficzne. Badania miały charakter dobrowolny, indywidualny, anonimowy. Zostały przeprowadzone zgodnie z założeniami Deklaracji Helsińskiej. Analizy materiału badawczego dokonano przy użyciu pakietu statystycznego STATISTICA 12 i programu Microsoft Office Excel. Przyjęto poziom istotności p<0,05, wskazujący na istotne statystycznie różnice bądź zależności. Posłużono się testem $\mathrm{Chi}^{2}$.

\section{WYNIKI}

Z przeprowadzonych badań wynika, że ankietowani przeważnie nie korzystali ze screeningu przeznaczonego do wykrycia choroby nowotworowej (66\%). Tylko 1/3 badanych wskazała na realizowanie badań profilaktycznych. Zazwyczaj były to: mammografia $(50 \%, n=17)$, USG $(47 \%, n=16)$, MRI $(6 \%, n=2)$, TK $(6 \%, n=2)$, RTG $(3 \%$, $n=1)$, scyntygrafia $(3 \%, n=1)$, biopsja $(3 \%, n=1)$, cytologia $(3 \%, n=1)$, kolonoskopia $(3 \%, n=1)$. Wystąpiła istotna statystycznie zależność między wiekiem $(\mathrm{p}=0,05)$, płcią $(\mathrm{p}=0,003)$, miejscem zamieszkania $(\mathrm{p}=0,04)$, a korzystaniem z badań profilaktycznych. Zaobserwowano, że wraz ze wiekiem badani częściej poddawali się screeningom. Kobiety $(43 \%, n=30)$ i mieszkańcy miast $(41 \%, n=27)$ znacznie częściej uczęszczali na badania profilaktyczne aniżeli mężczyźni $(13 \%, n=4)$ i ankietowani pochodzący ze wsi $(21 \%, n=7)$. Przeprowadzona analiza nie ujawniła istotnych statystycznie związków między pozostałymi zmiennymi socjo-demograficznymi, a korzystaniem ze screeningu. Jednakże zauważono, iż badaniom profilaktycznym poddawały się nieznacznie częściej osoby będące w związku (38\%, n=17), o średnim wykształceniu (37\%), z przeciętną lub złą sytuacją materialną (43\%). Uzyskane wyniki przedstawiono w tabeli 1 . 
Tab. 1. Korzystanie z badań profilaktycznych w zależności od zmiennych socjo-demograficznych

\begin{tabular}{|c|c|c|c|c|}
\hline \multirow{3}{*}{ Zmienna } & \multicolumn{4}{|c|}{ Korzystanie z badań profilaktycznych } \\
\hline & \multicolumn{2}{|c|}{ tak } & \multicolumn{2}{|c|}{ nie } \\
\hline & $\mathrm{n}$ & $\%$ & $\mathrm{n}$ & $\%$ \\
\hline \multicolumn{5}{|l|}{ Wiek } \\
\hline do 40 lat & 7 & 21 & 26 & 79 \\
\hline 41-50 lat & 8 & 30 & 19 & 70 \\
\hline powyżej 50 lat & 19 & 47,5 & 21 & 52,5 \\
\hline \multicolumn{5}{|c|}{ Analiza statystyczna: $\mathrm{Chi}^{2}=5,88 ; \mathrm{p}=0,05$} \\
\hline \multicolumn{5}{|l|}{ Płeć } \\
\hline kobiety & 30 & 43 & 39 & 57 \\
\hline mężczyźni & 4 & 13 & 27 & 87 \\
\hline \multicolumn{5}{|c|}{ Analiza statystyczna: $\mathrm{Chi}^{2}=8,91 ; \mathrm{p}=0,003$} \\
\hline \multicolumn{5}{|l|}{ Stan cywilny } \\
\hline wolny & 17 & 31 & 38 & 69 \\
\hline w związku & 17 & 38 & 28 & 62 \\
\hline \multicolumn{5}{|c|}{ Analiza statystyczna: $\mathrm{Chi}^{2}=0,52 ; \mathrm{p}=0,47$} \\
\hline \multicolumn{5}{|l|}{ Miejsce zamieszkania } \\
\hline miasto & 27 & 41 & 39 & 59 \\
\hline wieś & 7 & 21 & 27 & 79 \\
\hline \multicolumn{5}{|c|}{ Analiza statystyczna: $\mathrm{Chi}^{2}=4,13 ; \mathrm{p}=0,04$} \\
\hline \multicolumn{5}{|l|}{ Wykształcenie } \\
\hline podstawowe/zawodowe & 11 & 31 & 24 & 69 \\
\hline średnie & 18 & 37 & 31 & 63 \\
\hline wyższe & 5 & 31 & 11 & 69 \\
\hline \multicolumn{5}{|c|}{ Analiza statystyczna: $\mathrm{Chi}^{2}=0,32 ; \mathrm{p}=0,85$} \\
\hline \multicolumn{5}{|l|}{ Sytuacja materialna } \\
\hline dobra/bardzo dobra & 18 & 29 & 45 & 71 \\
\hline przeciętna/zła & 16 & 43 & 21 & 57 \\
\hline \multicolumn{5}{|c|}{ Analiza statystyczna: $\mathrm{Chi}^{2}=2,24 ; \mathrm{p}=0,13$} \\
\hline n - liczebność, \% - odset & otnośc & $i^{2}-w y$ & estu c & wadrat \\
\hline
\end{tabular}

\section{DYSKUSJA}

Wśród przyczyn niskiego rozpowszechnienia screeningu onkologicznego w Polsce Synowiec-Piłat wskazuje zjawisko społeczne, jakim jest cancerfobia, czyli fatalistyczne przekonania na temat raka [7]. Z kolei Marcinkowska i wsp. wyodrębnili cztery przyczyny niskiej frekwencji na badaniach przesiewowych: ekonomiczne, społeczne, organizacyjne, psychologiczne [8]. Badani argumentują nie poddawanie się badaniom profilaktycznym: niedbałością o zdrowie, niskim poczuciem świadomości zagrożenia zdrowia czy życia, odkładaniem badań na przyszłość, brakiem wolnego czasu, bagatelizowaniem problemu, brakiem wiary w skuteczność screeningu, skrępowaniem podczas badania, przekonaniem o jego bolesności. Niechęć do badań profilaktycznych spowodowana jest również ich złą organizacją, brakiem wiary w kompetencje lekarzy i sprawność sprzętu, oraz funkcjonującymi w społeczeństwie stereotypami ( „lepiej nie wiedzieç”, „nie trzeba wywolywać wilka $z$ lasu" itp.) [9-13].
Zatoński donosi, iż popularyzowanie badań profilaktycznych chorób nowotworowych powinno być skierowane $\mathrm{w}$ dużej mierze do kobiet $\mathrm{z}$ racji stale rosnącego odsetka zachorowalności i umieralności z powodu nowotworów u płci żeńskiej. Zwłaszcza zaś należy je upowszechniać w populacji o niskim wykształceniu i sytuacji ekonomicznej [14]. Zdaniem Wender wysyłanie imiennych zaproszeń do udziału w badaniach profilaktycznych jest jedną z najskuteczniejszych metod wzrostu zgłaszalności [15]. Z kolei według Szkieli i wsp. większą zgłaszalność na screening zapewnią proste, bezbolesne, nieinwazyjne, akceptowane społecznie badania [5]. Zdaniem Godlewskiego i wsp., badania przesiewowe powinny charakteryzować się wysoką swoistością, czułością i wartością testu, niskim kosztem, łatwością wykonania, dostępnością, bezinwazyjnością [16]. Marcinkowska i wsp. uważają, iż zwiększenie uczestnictwa w badaniach screeningowych możliwe jest do osiągnięcia przez stosowanie społecznych akcji informacyjnych uświadamiających korzyści płynące $\mathrm{z}$ regularnie podejmowanych badań. Podkreślają także istotną rolę lekarzy, zadaniem, których powinno być propagowanie badań profilaktycznych podczas codziennej praktyki [17]. Kulik i wsp. podkreślają kwestię niewystarczających środków finansowych w obrębie podstawowej opieki zdrowotnej przeznaczanych na profilaktykę chorób nowotworowych [18]. Huang i wsp. donoszą, iż z punktu widzenia ekonomii zdrowia wielce korzystne jest, aby prowadzić badania przesiewowe w kierunku raka [19]. Podobnie twierdzą Miller i wsp., zdaniem, których uczestnictwo w badaniach screeningowych poprawia wykrywanie chorób nowotworowych we wczesnym stadium rozwoju, tym samym pozwalając szybciej podjąć leczenie i znacznie ograniczyć jego koszty [20].

„W onkologii badania skryningowe mają na celu ujawnienie choroby nowotworowej w stadium bezobjawowym, czyli subklinicznym, co pozwala na znaczną wyleczalność nowotworów" [21]. Najbardziej skuteczne według Tuchowskiej i wsp. są badania przesiewowe mające na celu wykrycie raka szyjki macicy - cytologia, raka piersi - mammografia, USG i MR, raka jelita grubego test na krew utajoną i kolonoskopia [3]. Także Chudzik przywołuje wyżej wymienione badania, jako najczęściej stosowane i najefektywniejsze screeningi onkologiczne [22]. Ankietowani w badaniach autorskich poddawali się najczęściej mammografii, USG, MRI, TK, RTG, scyntygrafii, biopsji, cytologii, kolonoskopii.

Według Szynglarewicz i wsp., dobrze zorganizowany program badań przesiewowych może znacząco zmniejszyć umieralność z powodu chorób nowotworowych. Jednakże frekwencja kobiet z regionu Dolnego Śląska zaproszonych do udziału w badaniach mammograficznych wyniosła tylko $41 \%$ [23]. Pacian i wsp. oceniali poziom wiedzy oraz postawy kobiet pochodzących z makroregionu lubelskiego w zakresie profilaktyki nowotworu piersi. Jako główne źródła wiedzy o chorobie badane wymieniły Internet (56\%) i telewizję (53\%). Większość ankietowanych (74\%) znała podstawowe badania profilaktyczne wykrywające nowotwór piersi. Jednakże tylko połowa respondentek regularnie z nich korzysta. Badaczki podkreślają, 
iż konieczne jest ciągłe podnoszenie świadomości społecznej w zakresie chorób nowotworowych poprzez edukację zdrowotną oraz promocję zdrowego stylu życia [24]. Kozłowska i Kowalczyk oceniały poziom wiedzy i postaw pracowników biurowych wobec Programu Badań Przesiewowych dla Wczesnego Wykrywania Raka Jelita Grubego. Tylko $1 / 4$ badanych posiadała informacje na temat programu wczesnego wykrywania raka jelita grubego, przy czym częściej byli to mieszkańcy miast, kobiety, osoby po 50. r.ż, rozwiedzeni i obciążeni rodzinnie CRC. Wśród osób deklarujących znajomość programu tylko nieliczni dysponowali kompletną wiedzą na temat grupy docelowej omawianego badania przesiewowego. Pracownicy biurowi wykazywali niskie zainteresowanie screeningiem onkologicznym, a fakt obciążenia rodzinnego chorobą nowotworową nie skłaniał do zmiany tej postawy [6]. Wśród ankietowanych przez El Fakir i wsp. tylko 35,7\% wskazało na udział w badaniach screeningowych. Wśród nich przeważały mężatki, kobiety obciążone rodzinnie rakiem piersi [25]. Znacznie lepsze rezultaty osiągnęli Hofvind i wsp., gdyż frekwencja w norweskim programie badań przesiewowych raka piersi wyniosła 76,2\% [26]. Leżnicka i wsp. podkreślili rozbieżności w zgłaszalności kobiet na przesiewowe badania cytologiczne, która w Polsce wyniosła 11-32\%, a dla porównania w Danii 75\%, Holandii 77\% czy Finlandii 93\% [27]. Podobnie jak w zaprezentowanych doniesieniach tak i w badaniach własnych ankietowani wykazali się bardzo niskim zainteresowaniem screeningiem onkologicznym, który oszacowano na poziomie 34\%. Badaniom profilaktycznym poddawały się częściej osoby po 50. r.ż., pochodzące $z$ miasta będące w związku, o przeciętnej sytuacji finansowej i płci żeńskiej.

W badaniach Nowakowskiej i Kubary badani uważali za wielce istotne wykonywanie badań profilaktycznych oraz stosowanie się do zasad profilaktyki. „Mimo tego połowa respondentów zadeklarowała, że nie korzysta z programów profilaktycznych. Społeczeństwo ma więc świadomość istotności profilaktyki, ale nie znajduje to odzwierciedlenia w życiu codziennym” [28]. „Stwierdzenie, że „lepiej zapobiegać, niż leczyć”, jest - jak się wydaje - szeroko rozpowszechnione i ugruntowane w świadomości społecznej (...) W praktyce okazuje się jednak, że profilaktyka jest często niedoceniana i przypisuje się jej niejednokrotnie rolę drugorzędną. Zarówno społeczeństwo, jak i lekarze częstokroć skupiają uwagę na problemach diagnostyki oraz terapii, pomijając olbrzymi potencjał tkwiący właśnie w profilaktyce - pierwotnej i wtórnej rozumianej jako szereg działań mających na celu zmniejszenie prawdopodobieństwa zachorowania na nowotwór złośliwy" [29].

\section{WNIOSKI}

1. Z przeprowadzonych badań wynika, że ankietowani przeważnie nie korzystali ze screeningu przeznaczonego do wykrycia choroby nowotworowej.

2. Uczestnictwo $\mathrm{w}$ badaniach profilaktycznych determinowały wiek, płeć, miejsce zamieszkania badanych.
3. Na korzystanie z badań profilaktycznych nie wpływały stan cywilny, poziom wykształcenia i sytuacja materialna respondentów.

4. Proces ograniczenia zachorowalności i umieralności z powodu chorób nowotworowych wymaga większego uczestnictwa populacji w programach profilaktycznych.

\section{REFERENCES}

1. Zatoński W, Przewoźniak K. Ograniczanie zachorowalności i umieralności z powodu chorób nowotworowych. [in:] Szymborski J, ed. Public Health and Population Policy. Warszawa: Rządowa Rada Ludnościowa; 2012, p. 78-89.

2. Didkowska J, Wojciechowska U, eds. Nowotwory złośliwe w Polsce w 2013 roku. Warszawa: Centrum Onkologii - Instytut im. M. Skłodowskiej-Curie; 2015, p. 3.

3. Tuchowska P, Worach-Kardas H, Marcinkowski JT. Najczęstsze nowotwory złośliwe w Polsce - główne czynniki ryzyka i możliwości optymalizacji działań profilaktycznych. Probl Hig Epidemiol. 2013; 94(2): 166-171.

4. Strzelecki Z. Stanowisko Rządowej Rady Ludnościowej w sprawie „zachorowalności i umieralności na choroby nowotworowe oraz konieczności poprawy profilaktyki i wyników leczenia pacjentów nowotworowych w obliczu wyzwań demograficznych w Polsce". [in:] Potrykowska A, Strzelecki Z, Szymborski J, Witkowski J, eds. Zachorowalność i umieralność na nowotwory a sytuacja demograficzna Polski. Warszawa: Rządowa Rada Ludnościowa; 2014, p. 13-15.

5. Szkiela M, Worach-Kardas H, Marcinowski JT. Nowotwór złośliwy piersi epidemiologia, czynniki ryzyka, znaczenie profilaktyki pierwotnej i wtórnej. Probl Hig Epidemiol. 2014; 95(2): 292-302.

6. Kozłowska E, Kowalczyk A. Wiedza i postawy pracowników biurowych wobec Programu Badań Przesiewowych w kierunku wczesnego wykrycia nowotworu jelita grubego. J Educ Health Sport. 2015; 5(9): 443-456.

7. Synowiec-Piłat M. Taking decision about using medical services in view of the lay referral system concept. the case of oncological diseases. Acta Univ Lodz. 2013; 45 : 131-145.

8. Marcinkowska M, Mazurkiewicz P, Kozaka J, Stencel A. Przyczyny niskiej frekwencji kobiet w profilaktycznych badaniach mammograficznych. Psychoonkologia. 2006; 10(2): 57-63.

9. Kurpas D. Dostępność do badań profilaktycznych - rozwiązania w UE. Family Med E Primary Care Rev. 2011, 13(1): 75-79.

10. Gładczuk J, Maksimowicz K, Kleszczewska E. Wybrane aspekty profilaktyki chorób nowotworowych w Polsce. Część I. Czynniki determinujące zachowania profilaktyczne. Hygeia Public Health. 2015; 50(2): 266-271.

11. Dyzmann-Sroka A, Trojanowski M. Dlaczego Polki nie robią badań profilaktycznych? Now Lek. 2012; 81(3): 258-264.

12. Bojakowska U, Kalinowski P, Kowalska ME. Ocena skuteczności populacyjnego programu wczesnego wykrywania raka piersi wśród kobiet w Polsce. Pielęg Pol. 2013; 1(47): 18-22.

13. Dyzmann-Sroka A, Jędrzejczak A, Trojanowski M, Kubiak A. Przyczyny niskiej zgłaszalności Polek na badania profilaktyczne. Zeszyty naukowe WC0. 2010; 1(7): $17-27$.

14. Zatoński W. Europejski kodeks walki z rakiem. Warszawa: Centrum Onkologii Instytut im. Marii Skłodowskiej-Curie; 2009, p. 17-95.

15. Wender R. Barriers to screening for colorectal cancer. Gastrointest Endosc Clin N Am. 2002; 12(1): 145-70.

16. Godlewski D, Michalak J, Schroeiber T. Projektowanie badań przesiewowych w onkologii. Probl Hig Epidemiol. 2005; 86(1): 16-21.

17. Marcinkowska M, Mazurkiewicz P, Kozaka J, Stencel A. Przyczyny niskiej frekwencji kobiet w profilaktycznych badaniach mammograficznych. Psychoonkologia. 2006; 10(2): 57-63.

18. Kulik TB, Stefanowicz A, Pacian A, Żołnierczuk-Kieliszek D. Możliwości i ograniczenia profilaktyki chorób nowotworowych w podstawowej opiece zdrowotnej. Zdr Publ. 2004; 114(3): 275-278.

19. Huang $Q C$, Ye $D$, Jiang $X Y$ et al. Cost-effectiveness analysis on colorectal cancer screening program. Zhonghua Liu Xing Bing Xue Za Zhi. 2017; 38(1): 65-68.

20. Miller JD, Bonafede MM, Herschorn SD et al. Value Analysis of Digital Breast Tomosynthesis for Breast Cancer Screening in a US Medicaid Population. J Am Coll Radiol. 2017 Jan 26. pii: S1546-1440(16)31328-X. doi: 10.1016/j.jacr.2016.11.019.

21. Jakubowska-Najnigier M, Najnigier B. Rola badań przesiewowych w profilaktyce nowotworów. Medyczne Zeszyty Naukowe Uczelni Warszawskiej im. Marii Skłodowskiej-Curie. 2014; 2: 55-65. 
22. Chudzik M. Profilaktyka chorób nowotworowych - co możemy zrobić sami dla siebie? Medyczne Zeszyty Naukowe Uczelni Warszawskiej im. Marii SkłodowskiejCurie. 2014; 2: 31-44.

23. Szynglarewicz B, Matkowski R, Kasprzak P et al. The effectiveness of populationbased breast cancer screening programme. Pol Merkur Lekarski. 2009; 26(152): 117-120.

24. Pacian A, Kulik TB, Kaczoruk M, Kłodzińska K. Postawy kobiet makroregionu lubelskiego wobec profilaktyki nowotworu piersi. Med Paliat. 2016; 8(1): 17-23.

25. El Fakir S, Najdi A, Khazraji YC et al. Breast Cancer Screening in Morocco: Performance Indicators During Two Years of an Organized Programme. Asian Pac J Cancer Prev. 2015; 16(15): 6285-6288.

26. Hofvind S, Geller B, Vacek PM et al. Using the European guidelines to evaluate the Norwegian Breast Cancer Screening Program. Eur J Epidemiol. 2007; 22(7): 447-455.
27. Leżnicka M, Mierzwa T, Jachimowicz-Wołoszynek D, Żyrkowski J. System indywidualnych zaproszeń a zgłaszalność kobiet na badania profilaktyczne wykonywane w ramach programów z zakresu profilaktyki onkologicznej. Probl Hig Epidemiol. 2009; 90(2): 627-630.

28. Nowakowska I, Kubara K. We mnie jest moc! Czy społeczeństwo ma wiedzę na temat korzyści płynących z profilaktyki zdrowotnej? Pielęg Pol. 2015; 2(56): 149-152.

29. Hoffman B, Koper K. Profilaktyka chorób nowotworowych. [in:] Koper A, ed. Pielęgniarstwo onkologiczne. Warszawa: PZWL; 2015, p. 64-70.

Manuscript received/Praca przyjęta do druku: 06.06.2017

Manuscript accepted/Praca zaakceptowana do druku: 28.09.2017

Translation/Tłumaczenie: Anna Goś 